\title{
Implementation of Learning Model Aimed at Developing Social Competence of Third Age People
}

\author{
Innokenty A. Malanov ${ }^{1}$, Evgenia V. Miroshnichenko ${ }^{2}$, Natalia I. Shmonina ${ }^{2, *}$
}

\author{
${ }^{1}$ Buryat State University named after Dorji Banzarov, Ulan-Ude, Russia \\ ${ }^{2}$ Bratsk State University, Bratsk, Russia \\ *Corresponding author. Email: Natalya-shmonina@yandex.ru
}

\begin{abstract}
The article deals with the problem of development and implementation of the learning model aimed at developing social competence of the third age people. The problem of teaching people of the third age is relevant and is solved in the domestic and foreign studies from the standpoint of the formation and development of certain competencies in the context of continuing education. This research is based on a competence-based approach focused on the development of universal competencies including social competence. The model developed and implemented in the educational process of the Higher National School is based on andragogical and gerontological principles and includes four interrelated modules: target, content, organizational, and effective ones. A special place in the model is given to the program of social competence development. The implemented training model has shown its effectiveness in the development of social competence of the third age people and contributed to the socio-psychological adaptation, socialization and self-actualization of the people of the third age in the dynamics of modern society.
\end{abstract}

Keywords: Methodological basics for teaching third-age people, competence approach, competence, competency, continuing education, Higher National School, training of third-age people, social competence

\section{INTRODUCTION}

The society of XXI century has faced such a global problem as demographic aging of the population. This factor is increasingly influencing socio-economic and political processes in general. Therefore, nowadays special attention is paid widely to the problem of integrating older people into a modern, dynamically developing society. If earlier the post-labor period was considered a time of "survival" and older people were largely excluded from the production and economic life of society, today politicians, public organizations, and the scientific community pay attention to maintaining the independent and active position of older people, improving their quality of life, financial security, etc.

Elderly people have social, professional and spiritual potential and play a huge role in the development of modern society. Therefore, the main task facing the society is to create conditions and mechanisms for the effective use of this potential of older people and to preserve their active life position to solve the problems that arise. According to the modern researchers (L.I. Antsiferova [1], M. Ermolaeva [2], T.M. Kononygina [3], O.V. Krasnova [4], Martsinkovskaya [5] et al.) this can be achieved if we change the general attitude to old age itself and pay attention to the fact that this is a period of continuing development of the individual, this is a positive stage of human life filled with meaning. Therefore, the ideas of permanent (continuing) education in relation to elderly people are of particular importance. The analysis of scientific studies allows us to state that in pedagogical science there are basics and prerequisites for solving the problem of developing social competence of people of the third age in the training process. With all the variety of scientific studies, there is still the question of methodology of education of third age people, the learning format and the result are not clearly defined, educational activities for the elderly are not fully explored. At the same time the analysis of the teaching practice of elderly people shows the need for methodological tools focused on the study of the needs of elderly people, the study of their socio-psychological adaptation and socialization in the conditions of informatization of society and uncertainty, as well as the determination of the level of self-actualization.

Thus, the analysis of the state of the problem in pedagogical theory and practice allows us to identify the contradictions between:

- the requirements of the modern dynamically developing information society for the possession of certain socially significant competencies necessary for the success of human life and the lack of their formation among the people of the third age; 
- the need for integrating people of the third age into the modern information society and the insufficient level of understanding of this problem in the pedagogical theory;

- significant potential of educational activities for socialization for the socialization of people of the third age and the lack of scientific and methodological recommendations aimed at solving this problem.

The purpose of the study is to theoretically substantiate, develop and experimentally test a learning model aimed at developing social competence among the people of the third age.

\section{RESEARCH METHODS}

Initial theoretical-methodological basics and principles of the research were:

- the main ideas of a student-centered approach involving the creation of possibilities for self-change, selfimprovement and self-development of students, considering individual characteristics, capabilities and needs as the subject of learning and their own teaching activities (N.And. Alekseev, E.V. Bondarevskaya, D.G. Levites, O.L. Podlivaev, V.V. Serikov, V.I. Slobodchikov, L.M. Fridman, G.A. Tsukerman, I.S. Yakimanskaya, etc.); - scientific and theoretical provisions of the systemic activity approach which is focused on personal development in accordance with the requirements of the modern information society, considering a person with an active life position not only in training, but also in life (L.S. Vygotsky, P. Ya. Galperin, V.V. Davydov, A. Disterweg, A.N. Leontiev, V.V. Repkin, D.B. Elkonin, etc.);

- the main provisions of the synergetic approach in which learning is considered as a process of self-organization of the individual which determines the stable state of a new level; and also draws attention to the social selforganization of the group of students (E.N. Knyazeva, S.P. Kurdyumov, N.V. Poddubny, V.A. Khalanskaya, etc.);

- fundamental provisions of the competence approach which in contrast to the knowledge paradigm is focused on the development and formation of key (universal, social) competencies of the individual in the process of educational activity (V.V. Baydenko, V.A. Bolotov, A.A. Verbitsky, V.A. Isaev, I.A. Zimnaya, A.G. Kasprzhak, V.I. Slobodchikov, A.I. Subetto, A.V. Khutorskoy, M.A. Choshanov, S.E. Shishov, etc.).

Research methods: theoretical - interdisciplinary theoretical analysis of domestic and foreign sources on the problem, comparison, generalization, systematization, modeling; empirical-verbal and communicative methods (questionnaire, survey); testing; pedagogical experiment; modeling method; data processing methods - quantitative and qualitative processing of results. Statistical processing of the obtained actual data was performed using parametric and nonparametric criteria: U Mann-Whitney, t-student, $\chi 2$-Pearson.

\section{REVIEW OF SOURCES}

The review of the sources on the research problem (I.F. Albegova [6], V.P. Demidov [7], M.V. Ermolaeva [2], O.V. Krasnova [4], K.S. Poznańska [8], A.A. Rean [9], O.N. Startseva [10], O.V. Khukhlaeva [11], etc.) showed that the elderly people are the most socially vulnerable category of society. This age is accompanied by a lot of crisis moments that are hard for a person to experience. The characteristic features of the third age people are: loneliness, forced inactivity, depression, discouragement and frustration, a sense of their own inferiority and helplessness. At this age there are changes in the intellectual sphere, general cognitive abilities decrease, the intelligence of people of the third age is influenced by the life path, features of professional activity, educational level, etc. Another significant characteristic is the state of health. It affects the attitude of an elderly person and their self-esteem, as well as the quality of life in general. Having meaning in life also plays a prominent role in the lives of people of the third age. In the context of ongoing socio-economic transformations, rapid growth in the volume of knowledge, the introduction of information technologies in everyday life this category of the population especially requires the help of the government in obtaining modern knowledge in a clear and understandable form in all aspects of their life. It is the education in the modern society that is considered as the most important condition for a full life of people of any age including the aging period (S.G. Vershlovsky [12], M.T. Gromkova [13], S.I. Zmeev [14], M.E. elyutina [15], M.V. Ermolaeva [2], O.V. Krasnova [4], T.M. Kononygina [3], Yu. N. Kulyutkin [16], V.G. Onushkin [17], G.S. Sukhobskaya [18], etc.), which will also contribute to effective adaptation, socialization and selfactualization of the individual in a dynamically developing modern information society.

Under the concept of «third age» we consider the following - this is a new period of human life after retirement and termination of professional activity characterized by the continuation of an active lifestyle to realize their personal potential and opportunities.

Training people of the third age is a process based on the fundamentals of andragogy, herogogics carried out taking into account individual, psychological and social characteristics of students aimed at the realization of potential abilities, adaptation, socialization and selfactualization of people after retirement and termination of professional activity that provides them with social competence, but also allows you to develop an effective strategy of adaptive behavior and to learn to live with uncertainty.

Based on the analysis of theoretical approaches to understanding the essence of social competence of the individual, this concept was concretized in relation to people of the third age. Social competence of people of the third age - an integrative quality of personality that allows us to navigate situations of uncertainty, helps to 
fulfill a social role for the elderly and to carry out vital functions in society, by being active to maintain health, participation in public life, for further development, providing a higher level of quality of life [19].

As a result of the analysis of psychological and pedagogical sources, the learning model aimed at developing social competence of the third age people was developed which includes 4 interrelated modules: the target module is represented by the goal, objectives and principles of the process of developing social competence of third-age people; the content module represents the overall content of the program which provides the development of social competence of third-age people; the organizational module involves the creation and description of organizational aspects of the educational process; the effective module involves the analysis of the learning outcomes of people of the third age. This model assumes the implementation of a set of psychological and pedagogical conditions that influence the effectiveness of the development of social competence among people of the third age [20].

\section{CONCLUSION}

The conclusion obtained in the course of the theoretical research became the conceptual and methodological basics for experimental work aimed at determining the effectiveness of the model of teaching people of the third age to develop their social competence. The study involved 210 elderly people. The experimental group included 110 students of the Higher National School and the control group included 100 elderly people attending leisure centers.

The study included a number of necessary steps. Thus, at the ascertaining stage of the experiment it was revealed that the majority of test subjects in the experimental (EG) and control (CG) groups respectively, consider themselves cheerful 81 (56) \% and useful for society 77 (62) \%, which indicates that the interest in life is not lost and they are ready to go further in their self-development and selfimprovement. Most of the test subjects in both groups expressed the need for developing various competencies that will facilitate their integration into the modern dynamically developing information society.

According to the adaptability index the experimental and control groups had an average level of $35(27) \%$ and the lowest level of 31 (53)\% of the test subjects respectively. When studying the level of self-actualization, it was found that at the ascertaining stage of the experiment in EG and $\mathrm{CG}$ in general the test subjects had an average level of 47 (44)\% or level closer to it of $44(56) \%$. The overall indicator of meaningfulness of life among people of the third age in the experimental and control groups is characterized by a predominance of the average level. At the ascertaining stage of the experiment the majority of test subjects in both groups showed average - 58 (70)\% and low-36 (30) \% levels of readiness for age-related changes (integrative characteristic). Thus, the ascertaining stage of the experiment, including the use of various psychodiagnostic methods, showed an equally low initial level of development of social competence in the experimental and control groups.

The implementation of the learning model aimed at developing social competence of the third age people was carried out within the framework of the organization of experimental work. In the integral model of teaching people of the third age to develop their social competence a special place is taken by a specially developed and implemented training program in the educational process of the Higher National School (HNS) which acts as a formative stage of the experiment [21].

At the control stage of the experiment the effectiveness of the implementation of the third-age learning model aimed at developing social competence was tested. The obtained data indicate a positive dynamics in the development of social competence of people of the third age.

Qualitative analysis of empirical data suggests that after the formative stage of the experiment the respondents of the experimental group show greater adaptability (49\%) to the current conditions of uncertainty in comparison with the indicators of the ascertaining stage of the experiment (35\%) (questionnaire K. Rogers and R. Diamond).

After the method of self-actualization diagnostics being repeated, the experimental group observed a steady positive movement towards increasing the level of personal development of people of the third age from medium to high, from low to medium. Positive dynamics indicates the orientation of the test subjects' personality to further development, personal growth, knowledge of the internal and external world, the desire to increase the number of social roles, a positive attitude to their social status.

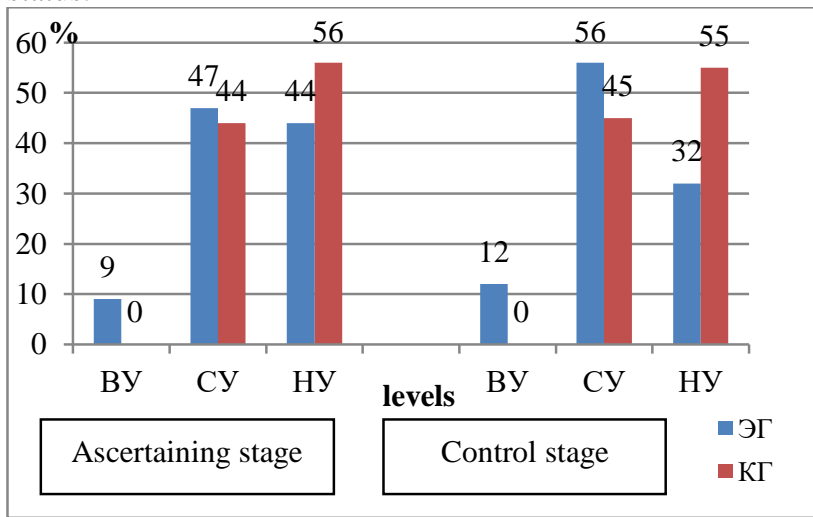

Figure 1 Comparative results of the self-actualization level of the third-age people in EG and CG (integrative approach)

Having studied the features of life orientations of people of the third age, we can conclude that after the formation stage of the experiment this indicator changed significantly in the experimental group, which indicates the importance of both the training itself for people of this 
age group and the importance of interpersonal communication, being in a group of like-minded people, etc. The results of the study show that after implementing a specially developed program in the experimental group there is a steady dynamics of increasing the indicator of meaningfulness of life for the third age people from the average to high, from low to average.

The comparative results of the level of readiness for age changes of the third age people in the experimental and control groups, obtained at the ascertaining and control stages of the experiment, showed that changes in the test subjects of EG occurred at all three levels.

Social competence is the key to active longevity and successful adaptation of the third age people. In modern socio-cultural conditions, addressing the issue of training older people is timely and relevant. The available studies on the problem of adult education allowed us to develop the author's model of teaching people of the third age, the basis of which is the program for the development of social competence. The conducted experimental work has shown that psychological and pedagogical support for people of the third age will contribute to the development of adaptive mechanisms, acceptance of the changed life situation, sufficient communication and daily activity, preservation of interest in life, expansion and change of the environment and habitual life sphere. All of the above will allow the elderly people to integrate into modern society. Developing a readiness for age-related changes, understanding the naturalness of these processes and, despite the emerging feelings of physical impairment, people of the third age are looking for new areas for selfrealization where they can get new experiences and maintain a sense of need for society. This is the sphere of education for them.

The implementation of the social competence development program for the students of the High National School has had a positive impact on the actualization of personality resources of the third age people to improve the life quality; it allowed rethinking the attitude to themselves, to their social status, to their past, current time, future; to psycho-physiological changes occurring at this age stage, finding the meaning of life.

This study does not exhaust the whole range of problems related to the development of social competence of the third age people in the process of learning, increasing the level of their socio-psychological adaptation, socialization and further self-realization and self-actualization at the later stages of ontogenesis.

\section{REFERENCES}

[1] L.I. Antsyferova, New stages of late life: time of warm autumn or harsh winter?, Psychological journal 153 (1994) 99-105.
[2] M.V. Ermolaeva, Psychological and pedagogical support of an elderly person: a subject approach, $\mathrm{PhD}$, thesis in Psychology, 2010.

[3] T.M. Kononygina, Gerontological Education: towards the needs of the elderly, Continuing education in political and economic contexts, IS RAN, 2008.

[4] O.V. Krasnova, Social psychology of aging as the main component of social gerontology, World of psychology 2 (1999) 96-106.

[5] T.D. Martsinkovskaya, Psychology of development, Publishing center "Academy”, 2014.

[6] I.F. Albegova, O.N. Startseva, Gerontological Education: Educational guide, Socium, 2014.

[7] V.P. Demidov, Old Age as a socio-philosophical phenomenon: abstract of thesis, 2005.

[8] K.S. Poznanski, Psychological characteristics of the elderly, Available at: http://www.b17.ru/article/11589/.

[9] O.N. Startseva, Development and implementation of a therapeutic environment for the elderly in a stationary social service institution, abstract of thesis, 2017.

[10] The psychology of man from birth to death, A complete course in developmental psychology, Primeeuroznak, 2003.

[11] O.V. Khukhlaeva, Psychology of development: youth, maturity, old age, Publishing center "Academy", 2002.

[12] S.G. Vershlovsky, Adult as a subject of education, Pedagogy 8 (2003) 3-8.

[13] M.T. Gromkova, Andragogika: theory and practice of adult education, UNITY-DANA, 2015.

[14] S.I. Zmeev, Adult education and andragogy in the implementation of the concept of continuing education in Russia, Domestic and foreign pedagogy 3 (24) (2015), Available at:

https://cyberleninka.ru/article/n/obrazovanie-vzroslyhi-andragogika-v-realizatsii-kontseptsii-nepreryvnogoobrazovaniya-v-rossii.

[15] M.E. Elyutina, G.I. Bolotov, Everyday life of an elderly family: strategy of planning and austerity of resources, Izv. Sarat. UN-TA New ser. Ser. Sociology, Political science, 2017, Available at: 
https://cyberleninka.ru/article/n/povsednevnaya-zhiznpozhiloy-semi-strategiya-planirovaniya-i-zhestkoyekonomii-resursov.

[16] Y. Kulyutkin, Dialogue in adult education, New knowledge: Journal on problems of adult education 4 (1999) 28-30.

[17] V.G. Onushkin, Yu.N. Kulyutkin, Adult education as a subject of research, Soviet Pedagogy 6 (1984) 86-94.

[18] G.S. Sukhobskaya, Conditions for inclusion of elderly people as active subjects in the life of modern society, Social worker as andragogist, 2001.

[19] I.A. Malanov, N.I. Shmonina, Competence approach in teaching people of the third age, in: Improving the quality of education: proceedings of XVI (XXXII) All-Russian scientific and methodological conference, In 2 volumes-Bratsk, BrSU Publishing House, 2019, Part 1, pp. 243-246.

[20] I.A. Malanov, N.I. Shmonina, Features of modeling the learning process of the "third" age people, in: Proceedings of the Bratsk State University, Series: Humanities and Social Sciences, 2019, pp. 8792.

[21] N.I. Shmonina, Justification of the training program for the «third» age people in the Higher National School, Modern pedagogical education 2 (2018) 148-150. 